Volume. 2 Nomor. 2

Periode: Juli - Desember 2018; hal. 31-38

p-ISSN : 2580-1112; e-ISSN : 2655-6669

Copyrighr@2018

Penulis memiliki hak cipta atas artikel ini

Jurnal Ilmiah Keperawatan Orthopedi (JIKO)

journal homepage:

https://ejournal.akperfatmawati.ac.id

\title{
Pengaruh Balance Exercise Terhadap Keseimbangan Tubuh Lansia di Desa Singocandi Kabupaten Kudus
}

\author{
Anita Dyah Listyarini ${ }^{1}$, Galia Wardha Alvita ${ }^{2}$ \\ Bidang Keperawatan Komunitas PSIK STIKES Cendekia Utama Kudus
}

\begin{abstract}
Abstrak
Proses menua merupakan proses alami yang dapat terjadi pada manusia. Penuaan dapat menyebabkan perubahan fisiologis sistem muskuloskeletal yang bervariasi. Salah satu diantaranya adalah perubahan struktur otot, yaitu penurunan jumlah dan ukuran serabut otot (atrofi otot). Dampak perubahan morfologis pada otot ini dapat menurunkan kekuatan otot sehingga dapat menganggu keseimbangan tubuh lansia. Gangguan keseimbangan tubuh lansia dapat dikurangi dan dicegah dengan melakukan latihan fisik. Balance exercise merupakan latihan fisik pada lansia yang dapat mengurangi dan mencegah gangguan keseimbangan tubuh lansia. Tujuan penelitian ini adalah mengetahui pengaruh balance exercise terhadap keseimbangan tubuh lansia. Jenis penelitian ini adalah experiment research dengan rancangan One group Pretest-Postest With Control Design. Jumlah sampel 70 responden dengan 35 sampel kelompok intervensi dan 35 sampel kelompok control (non intervensi) pengambilan sampel menggunakan teknik total sampling sesuai kriteria inklusi dan eksklusi. Analisis penelitian ini menggunakan UjiWilcoxon. Hasil penelitian menunjukkan ada pengaruh balance exercise terhadap keseimbangan tubuh lansia pada kelompok eksperimen dan tidak adanya pengaruh keseimbangan tubuh lansia pada kelompok non eksperimen karena pada kelompok non eksperimen ini tidak diberikan intervensi dengan $p$ value kelompok eksperimen $=0,000(P$ $<0.05)$ dan kelompok non eksperimen p-value 0.317 ( $p>0,05)$. Kesimpulan penelitian ini adalah ada pengaruh balance exercise pada kelompok eksperimen dan tidak ada pengaruh keseimbangan tubuh dengan balance exercise pada kelompok non eksperimen di Desa Singocandi Kudus.
\end{abstract}

Kata Kunci: Balance Exercise, Keseimbangan Tubuh, Lansia

\begin{abstract}
The process of aging is a natural process that can occur in all living things. Aging can cause physiological changes in the musculoskeletal system including muscle structure, such as a decrease in the number and size of muscle fibers (muscle atrophy). The impact of morphological changes in muscle can reduce muscle strength that can disturb the balance of the body of the elderly. Elderly body balance disorders can be reduced and prevented by physical exercise. The purpose of this study was to analize the effect of balance exercise toward balance body of elderly. This study usedquasy experiment design using one group pretest-posttestwith control group. A total of 70 respondents with 35
\end{abstract}

1,2 e-mail: anitahapsoro@yahoo.co.id 
samples of the intervention group and 35 samples of the control group (non-intervention) were recruited using total sampling technique. The wilcoxon test was used for analyzing data. The results revealed thatbalance exercise influence on the body balance of elderly in the experimental group with $p$ value $=0.000(P<0.05)$ and the absence of influence on body balance of elderly in non-experimental group (p-value 0.317). In conclusion, there was effect of balance exercise in the experimental group and no effect in body balance on non-experimental group in the village Singocandi Kudus.

\section{Keywords :Balance Exercise, Balance The Body, The Elderly}

\section{Pendahuluan}

Lansia merupakan kelompok penduduk yang usianya lebih dari 60 tahun keatas yang mengalami proses menuadan perlu beradaptasi dengan berbagai perubahan fungsi dan stress lingkungan akibat terjadinya penurunan kemampuan tubuh (Setiabudhi, 2009). Penuaan dapat menyebabkan perubahan fisiologis sistem muskuloskeletal yang bervariasi. Salah satu diantaranya adalah perubahan struktur otot, yaitu penurunan jumlah dan ukuran serabut otot (atrofi otot). Dampak perubahan morfologis pada otot ini dapat menurunkan kekuatan otot (Pudjiastuti, 2003). Penurunan kekuatan otot ekstrimitas bawah dapat mengakibatkan kelambanan gerak, langkah yang pendek, kaki tidak dapat menapak dengan kuat dan lebih gampang goyah, keseimbangan menjadi terganggu (Nugroho 2005; Darmojo, 2007).

Gangguan keseimbangan adalah ketidakmampuan lansia untuk mempertahankan pusat gravitasi ketika dalam posisi tegak (Suyanto, 2010). Gangguan keseimbangan postural merupakan hal yang sering terjadi pada lansia. Menurut Kane (1994) dalam Suyanto (2010) jika keseimbangan postural lansia tidak dikontrol, maka akan dapat meningkatkan resiko jatuh (Siburian, 2006). Gunarto (2005) menyatakan bahwa $31 \%$ - $48 \%$ lansia jatuh karena gangguan keseimbangan.

Pada lansia yang mempunyai mobilitas fisik yang tinggi akan meningkatkan kontrol keseimbangan fisiknya, sehingga resiko jatuh sangat rendah (Guccione, 2004). Mobilitas yang baik dapat diperoleh dengan melakukan latihan fisik yang berguna untuk menjaga agar fungsi sendi-sendi dan postur tubuh tetap baik. Latihan dilakukan secara bertahap, disesuaikan dengan kemampuan lansia (Siburian, 2006). Salah satu bentuk latihan fisik adalah balance exercise. Disampaikan oleh Nyman tahun 2007 bahwa latihan balance exercise adalah suatu aktivitas fisik yang dilakukan untuk meningkatkan kestabilan tubuh dengan cara meningkatkan kekuatan otot anggota gerak bawah. Hal ini diperkuat penelitian Rahayu (2013), menunjukkan bahwa setelah responden diberikan balance exercise 2 kali dalam seminggu selama 3 minggu keseimbangan posturalnya mengalami peningkatan dari rata-rata nilai Berg Balance Scale 32 sebelum diberikan balance exercise menjadi 47.8 setelah diberikan balance exercise.

Sedangkan Madureira (2006), mengungkapkan bahwa latihan keseimbangan sangat efektif untuk meningkatkan keseimbangan fungsional dan statis serta mobilitas lansia. Latihan keseimbangan ini juga akan menurunkan frekuensi jatuh pada lansia, bila dilakukan dengan frekuensi optimal 2 kali dalam seminggu selama 3 minggu.

Berdasarkan survey pendahuluan yang dilakukan peneliti di RW 3 desa Singocandi Kabupaten Kudus terdapat58 lansia yang aktif dalam beraktifitas sehari hari adalah 35 lansia. Peneliti melakukan uji sampling kepada 5 lansia dengan cara disuruh berdiri tegap selama 1 menit, didapatkan hasil 4 lansia tidak dapat berdiri tegap dan 1 lansia dapat berdiri tegap sampai satu menit. Berdasarkan wawancara lansia selama dirumah lebih 
banyak istirahat dan jarang melakukan aktifitas fisik seperti ke sawah, kekebun, ke ladang dan olah raga. Hal ini yang menyebabkan peneliti tertarik untuk melakukan penelitian tentang pengaruhbalance exercise terhadap keseimbangan tubuh lansia di Desa Singocandi Kabupaten Kudus.

\section{Metode Penelitian}

Jenis penelitian yang digunakan adalah Quasy-experiment (Eksperimen Semu), yang tujuannya untuk mengetahui suatu gejala atau pengaruh yang timbul, sebagai akibat dari adanya perlakuan tertentu, percobaan itu berupa perlakuan atau intervensi terhadap suatu variabel.
Rancangan penelitian yang dilakukan adalah One group PretestPostest With Control Design. Dalam rancangan penelitian ini subyek control dan kelompok intervensi dilakukan pengukuran awal (pretest) kemudian kelompok intervensi dikenai perlakuan yaitu senam keseimbangan, sedangkan kelompok control tidak diberikan, kemudian dilakukan pengukuran akhir pada kelompok control dan kelompok perlakuan (posttest).

\section{Hasil Penelitian}

Karakteristik responden

Karakteristik responden berdasarkan jenis kelamin.

Tabel 1. Distribusi Frekuensi Responden Berdasarkan Jenis Kelamin Kelompok Intervensi dan Non di Desa Singocandi Kudus ( $\mathrm{n}=35)$

\begin{tabular}{ccccccc}
\hline \multirow{2}{*}{ Variabel } & \multicolumn{3}{c}{ Intervensi } & \multicolumn{3}{c}{ Non Intervensi } \\
\cline { 2 - 7 } & Kategori & $\mathrm{F}$ & \multicolumn{2}{c}{$\%$} & $\mathrm{~F}$ & $\%$ \\
\hline Jenis Kelamin & Laki-laki & 17 & 48.6 & 15 & 42.9 \\
& Perempuan & 18 & 51.4 & 20 & 57.1 \\
\hline \multicolumn{2}{c}{ Total } & 35 & 100.0 & 35 & 100.0 \\
\hline
\end{tabular}

Berdasarkan Tabel 1 menunjukkan bahwa pada kelompok intervensi responden sebagian besar berjenis kelamin perempuansebanyak 18 $(51,4 \%)$. Pada kelompok kontrol sebagian besar responden berjenis kelamin perempuan sebanyak 20 (7,2\%).

Karakteristik Responden Berdasarkan Umur

Tabel 2. Distribusi Frekuensi Responden Berdasarkan Umur Kelompok Intervensi dan Non di Singocandi Kudus ( $\mathrm{n}=35$ )

\begin{tabular}{ccccc}
\hline Variabel umur & \multicolumn{2}{c}{ Intervensi } & \multicolumn{2}{c}{ Non Intervensi } \\
& $\mathbf{F}$ & $\mathbf{\%}$ & $\mathbf{F}$ & $\%$ \\
60-65 Tahun & 23 & 65.7 & 22 & 62.9 \\
66-70 Tahun & 12 & 34.3 & 13 & 37.1 \\
\hline Total & 35 & 100.0 & 35 & 100.0 \\
\hline
\end{tabular}

Berdasarkan tabel 2 dapat diketahui distribusi umur dari 35 responden di dapatkan usia responden pada kelompok intervensi sebagian besar responden berusia $60-65$ tahun sebanyak 23 responden $(65,7 \%)$ dan pada kelompok non intervensi sebagian besar berusia 60-65 tahun sebanyak 22 responden $(62,9 \%)$.

Analisis Univariat

Keseimbangan Tubuh Lansia Sebelum dan sesudah dilakukan Balance Exercise Pada Kelompok Intervensi 
Tabel 3. Distribusi Frekuensi Keseimbangan Tubuh Lansia Sebelum dan Sesudah Balance Exercise di Singocandi Kudus ( $\mathrm{n}=35)$

\begin{tabular}{ccccc}
\hline Kategori & \multicolumn{4}{c}{ Intervensi } \\
& \multicolumn{3}{c}{ Pre } & \multicolumn{2}{c}{ Post } \\
\cline { 2 - 5 } & F & \% & F & \% \\
\hline Keseimbangan Baik & 8 & 22.9 & 26 & 74.3 \\
Keseimbangan Cukup & 24 & 68.6 & 9 & 25.7 \\
Gangguan Keseimbangan & 3 & 8.6 & - & - \\
\hline Total & 35 & 100 & 35 & 100 \\
\hline
\end{tabular}

Berdasarkan tabel 3 menunjukkan bahwa distribusi frekuensi keseimbangan tubuh lansia sebelum dan sesudah dilakukan balance exercise di Posyandu lansia "Seger Waras" didapatkan hasil sebelum intervensi sebagian besar lansia mengalami keseimbangan tubuh cukup sebanyak 24 responden $(68,6 \%)$ dan sesudah intervensi balance exercise sebagian besar lansia menjadi keseimbangan baik sebanyak 26 responden $(74,3 \%)$.

Keseimbangan Tubuh Lansia Pada kelompok Non Intervensi (Tidak dilakukan balance exercise)

Tabel 4. Distribusi Frekuensi Keseimbangan Tubuh Lansia Pada kelompok Non Intervensi di Singocandi Kudus ( $n=35)$

\begin{tabular}{ccccc}
\hline \multirow{2}{*}{ Kategori } & \multicolumn{3}{c}{ Non Intervensi } \\
& \multicolumn{2}{c}{ Pre } & \multicolumn{2}{c}{ Post } \\
\cline { 2 - 5 } & F & \% & F & \% \\
\hline Keseimbangan Baik & 8 & 22.9 & 10 & 28.6 \\
Keseimbangan Cukup & 25 & 71.4 & 24 & 68.6 \\
Gangguan Keseimbangan & 2 & 5.7 & 1 & 2.9 \\
\hline Total & 35 & 100 & 35 & 100 \\
\hline
\end{tabular}

Berdasarkan tabel 4 menunjukkan bahwa distribusi frekuensi keseimbangan tubuh lansia pada kelompok non intervensi di Singocandi Kudus didapatkan hasil sebagian besar hasil awal adalah keseimbangan cukup sebanyak 25 responden $(71,4 \%)$ dan tanpa dilakukan intervensi di hitang keseimbangan tubuh lansia didapatkan hasil sebagian besar keseimbangan kurang sebanyak 24 responden $(68,6 \%)$.

Analisa Bivariat

Analisa bivariat dalam penelitian ini

Hasil Uji Wilcoxonpada Balance Exercise terhadap keseimbangan tubuh lansia Pada kelompok Intervensi dan Non Intervensi.

Tabel 5 Balance Exercise Tterhadap Keseimbangan Tubuh Lansia Pada Kelompok Intervensi dan Non Intervensi Desa Singocandi $(n=35)$

\begin{tabular}{|c|c|c|c|c|c|}
\hline \multirow{2}{*}{ Variabel } & \multirow{2}{*}{ Ranks } & \multicolumn{3}{|c|}{ Intervensi } & \multirow{2}{*}{$\begin{array}{l}\text { Non Intervensi } \\
\text { p value }\end{array}$} \\
\hline & & $\mathbf{N}$ & p value & $\mathbf{N}$ & \\
\hline \multirow{4}{*}{$\begin{array}{l}\text { Keseimbangan Tubuh } \\
\text { Lansia Sebelum dan } \\
\text { Sesudah dilakukan } \\
\text { Balance Exercise }\end{array}$} & $\begin{array}{l}\text { Negative } \\
\text { Ranks }\end{array}$ & 0 & \multirow{4}{*}{.000} & & \multirow{4}{*}{.317} \\
\hline & Positive & 20 & & & \\
\hline & Ties & 15 & & & \\
\hline & Total & 35 & & & \\
\hline
\end{tabular}


Berdasarkan Tabel 5.6 hasil uji statistik menggunakan uji nonparametrikWilcoxon pada lansia di Singocandi yang diberikan intervensi balance exercise menunjukkan adanya peningkatan keseimbangan tubuh lansia/ positif rangking sebanyak 20 responden dan yang tidak mengalami peningkatan keseimbangan tubuh lansia atau penurunan (tetap) perilaku sebanyak 15 responden dengan p-value $0,000 \quad(p<$ $0,05)$.

Hal ini menunjukkan adanya
pengaruh yang signifikan pada
pemberian intervensi balance exercise
terhadap keseimbangan tubuh lansia di
Singocandi Kudus.

Hasil uji statistik kelompok non intervensi untuk mengetahui perbedaan pre test non intervensi dengan post test non intervensi dengan menggunakan uji nonparametrikWilcoxon menunjukkan adanya penurunan keseimbangan tubuh lansia/negatif rangking sebanyak 6 responden, yang mengalami peningkatan keseimbangan tubuh lansia/positif rangking sebanyak 3 responden dan yang tetap sebanyak 26 responden dengan $\mathrm{p}$ value $0.317(p>0,05)$.

Dari hasil tersebut dapat disimpulkan tidak adanya pengaruh keseimbangan tubuh lansia pada kelompok non eksperimen karena pada kelompok non eksperimen ini tidak diberikan intervensi/perlakuan.

\section{Hasil Man Withney pada Balance Exercise terhadap keseimbangan tubuh lansia Pada kelompok Intervensi dan Non Intervensi.}

Tabel 7. Balance Exercise terhadap keseimbangan tubuh lansia Pada kelompok Intervensi dan Non Intervensi Desa Singocandi Kudus ( $n=35)$

\begin{tabular}{cccc}
\hline \multirow{2}{*}{ Kelompok } & \multirow{2}{*}{} & Pre & Post \\
\cline { 3 - 4 } & & p-value & p-value \\
\hline Eksperimen & 35 & .400 & .000 \\
Non Eksperimen & 35 & Tidak Ada Pengaruh & Ada pengaruh \\
Total & 70 &
\end{tabular}

Hasil uji statistik untuk mengetahui perbedaan pre test eksperimen dengan pre test non eksperimen dengan menggunakan uji nonparametric Man Withney didapatkan p-value 0,400 (lebih dari 0,05).

Hal ini menunjukkan tidak adanya pengaruh yang signifikan antara pre test eksperimen dengan pre test non eksperimen.

\section{Pembahasan}

Hasil uji statistik menggunakan uji nonparametrikWilcoxon pada lansia di Posyandu Lansia "Seger Waras" yang diberikan intervensi balance exercise menunjukkan p-value 0,000 $(p<0,05)$.

Hal ini menunjukkan adanya pengaruh yang signifikan pada pemberian intervensi balance exercise terhadap keseimbangan tubuh lansia di
Sedangkan untuk mengetahui perbedaan post test eksperimen dengan post test non eksperimen didapatkan $\mathrm{p}$ value 0,000 (kurang dari 0,05), hal ini menunjukkan adanya pengaruh yang signifikan karena pada kelompok eksperimen diberikan perlakuan berupa balance exercise sedangkan pada kelompok non eksperimen tidak diberikan perlakuan. Posyandu Lansia "Seger Waras" RW III Desa Tenggeles Mejobo Kudus.

Sedangkan pada kelompok control menunjukkan P-Value 0,317 artinya pada kelompok control tidak ada perbedaan tingkat keseimbangan pre dan post tes.

Sedangkan hasil uji statistik
kelompok non intervensi untuk
mengetahui perbedaan pre test non
intervensi dengan post test non intervensi
dengan menggunakan uji nonparametric


Wilcoxon menunjukkan adanya penurunan keseimbangan tubuh lansia/negatif rangking sebanyak 6 responden, yang mengalami peningkatan keseimbangan tubuh lansia/positif rangking sebanyak 3 responden dan yang tetap sebanyak 26 responden dengan $\mathrm{p}$ value $0.317(p>0,05)$

Dari hasil tersebut dapat disimpulkan tidak adanya pengaruh keseimbangan tubuh lansia pada kelompok non eksperimen karena pada kelompok non eksperimen ini tidak diberikan intervensi/perlakuan. Sedangkan untuk mengetahui perbedaan post test eksperimen pada uji Mann Withney dengan post test non eksperimen didapatkan p-value 0,000 (kurang dari 0,05).

Hal ini menunjukkan adanya pengaruh yang signifikan balance exercise pada kekuatan otot lansia pada kelompok eksperimen dan tidak ada pengaruh signifikan balance exercise pada kekuatan otot lansia pada kelompok non eksperimen.

Lansia merupakan sekelompok manusia yang mengalami proses menua secara faali diamana terjadi penurunan semua kemampuan tubuh, salah satunya terjadi penurunan fungsi sistem muscoloskletal tubuh (Maryam, 2008). Salah satu gangguan sistem muscoloskletal tubuh lansia adalah keseimbangan tubuh lansia.

Keseimbangan adalah kemampuan untuk mempertahankan pusat gravitasi atas dasar dukungan, biasanya ketika dalam posisi tegak maupun berjalan (Batson, 2009). Faktor yang mempengaruhi keseimbangan antara lain, pusat gravitasi, penyakit tulang dan kekuatan otot (Taylor, 2004).

Penurunan kekuatan otot ekstrimitas bawah dapat mengakibatkan kelambanan gerak, langkah yang pendek, kaki tidak dapat menapak dengan kuat dan lebih gampang goyah (Darmojo, 2007). Penurunan kekuatan otot juga menyebabkan terjadinya penurunan mobilitas pada lansia. Karena kekuatan otot merupakan komponen utama dari kemampuan melangkah, berjalan dan keseimbangan. Sehingga pada lansia sering mengalami jatuh. (Suyanto, 2010).

Salah satu solusi untuk mengatasi dan mencegah adanya gangguan keseimbangan ini adalah upaya pemberian latihan, salah satunya adalah balance exercise. Disampaikan oleh Nyman tahun 2007 bahwa latihan balance exercise adalah suatu aktivitas fisik yang dilakukan untuk meningkatkan kestabilan tubuh dengan cara meningkatkan kekuatan otot anggota gerak bawah.

Sedangkan Madureira (2006) dan Skelton (2001), mengungkapkan bahwa latihan keseimbangan sangat efektif untuk meningkatkan keseimbangan fungsional dan statis serta mobilitas lansia. Latihan keseimbangan ini juga akan menurunkan frekuensi jatuh pada lansia, bila dilakukan dengan frekuensi optimal 2 kali dalam seminggu selama 3 minggu.

Berdasarkan hasil penelitian, peneliti menyimpulkan bahwa, pada posyandu lansia "Seger Waras" RW III Desa Tenggeles yang diberikan intervensi balance exercise pada lansia terjadi perubahan yang signifikan pada sebelum dan sesudah intervensi.

Peningkatan nilai keseimbangan tubuh lansia dari sebagian besar sebelumnya keseimbangan cukup sebanyak sebanyak 24 responden $(68,6 \%)$ dan sesudah intervensi balance exercise sebagian besar lansia menjadi keseimbangan baik sebanyak 26 responden $(74,3 \%)$.

Hal ini dikarenakan lansia menjalani latihan balance exercise selama 3 kali selama 3 minggu sehingga terjadi peningkatan kekuatan otot dan keseimbangan tubuh lansia.

Sedangkan pada Posyandu Lansia RW II Desa Tenggeles sebagai kelompok non intervensi (control) tidak dilakukan latihan balance exercise pada lansia, dimana tidak terjadi perubahan 
keseimbangan tubuh lansia yang signifikan.

Hal ini terlihat pada hasil pengukuran pre post non intervensi didapatkan keseimbangan pre non intervensi sebanyak 25 responden $(71,4 \%)$ mengalami keseimbangan kurang dan post non intervensi sebagian besar keseimbangan kurang sebanyak 24 responden $(68,6 \%)$.

Hal ini diperkuat oleh penelitian Kusnanto (2010) tentang peningkatan stabilitas posturan pada lansia dengan latihan balance exercise didapatkan hasil bahwa lansia yang melakukan latihan keseimbangan dengan balance exercise lebih meningkat keseimbangannya dibandingkan lansia yang tidak melakukan latihan, dengan hasil uji statistik didapatkan $\mathrm{p}$ value 0,002 $(\mathrm{p}<0,05)$.

\section{Kesimpulan}

1. Hasil uji statistik menggunakan uji Wilcoxon pada lansia di Posyandu Lansia "Seger Waras" yang diberikan intervensi balance exercise didapatkan nilai $p$-value $0,000(p<0,05)$. Hal ini menunjukkan adanya pengaruh yang signifikan pada pemberian intervensi balance exercise terhadap keseimbangan tubuh lansia di Posyandu Lansia "Seger Waras" RW III Desa Tenggeles Mejobo Kudus.

2. Hasil uji statistik kelompok non intervensi menggunakan uji Wilcoxon didapatkan nilai $p$-value 0.317 ( $p>$ 0,05). Dari hasil tersebut dapat disimpulkan tidak adanya pengaruh keseimbangan tubuh lansia pada kelompok non eksperimen karena pada kelompok non eksperimen ini tidak diberikan intervensi/perlakuan.

\section{Daftar Psutaka}

[1] Arikunto, Suharsimi. 2010. Prosedur Penelitian Suatu Pendekatan Praktik. Jakarta: Rineka Cipta
[2] Azizah, Lilik Ma'rifatul.2011. Keperawatan Lanjut Usia.Yogyakarta: Graha Ilmu

[3] Darmojo, R.B.\& Martono, H.H. 2007. Geriatri (Ilmu Kesehatan Usia Lanjut). Jakarta: Balai Penerbit FKUI.

[4] Depkes RI. 2008. Pedoman Pembinaan Kesehatan Usia Lanjut bagi Petugas Kesehatan. Jakarta: Direktorat Bina Kesehatan Keluarga.

[5] Dinas Kesehatan Kabupaten Kudus. 2014. Data Lansia di Wilayah Kabupaten Kudus.

[6] Gleen John. 2007. About Strenght/balance exercise

[7] Guccione, AA. 2004. Geriatric Physical Therapy. $2^{\text {nd }} \cdot$ Edition. Philadelpia: Mosby.

[8] Gunarto, S., Tohamuslim, A., \& Aries, W. (2005). Pengaruh Latihan Four Square Step terhadap Keseimbangan pada Lanjut Usia. Tesis. Jakarta: FKUI.

[9] Guyton, Arthur C. 2002. Buku Ajar Fisiologi Kedokteran. Jakarta: EGC

[10] Hidayat, A.Aziz. 2007. Metotelogi Penelitian Keperawatan dan Tehnik Analisa Data. Jakarta : Salemba Medica

[11] http://weboflife.ksc.nasa.gov/exercis eandaging/chapter4 balance.html. Diakses tanggal 13 April 2007

[12] Kozier,dkk. 2010. Fundamental Keperawatan Konsep, Proses dan Praktik. Jakarta : EGC

[13] Kusnanto, Indarwati, R. dan Mufidah, N. 2010. Peningkatan Stabilitas Postural Pada Lansia Melalui Balance Exercise. http://ejournal.undip.ac.id/index.php /medianers/article/viewFile/716/pdf diperoleh tanggal 15 Februari 2015

[14] Maryam, R.S., dkk. 2011.Mengenal Usia Lanjut dan Perawatannya. Jakarta: Salemba Medika

[15] Maryam, R.S., Sahar, J., \& Nasution, Y. (2010). Pengaruh Latihan Keseimbangan Fisik Terhadap Keseimbangan Tubuh Lansia Di Panti Sosial Tresna 
Werdha Wilayah Pemda DKI Jakarta

http://isjd.pdii.lipi.go.id/admin/jurna 1/2110917_2085-8930.pdf diperoleh tanggal 12 Februari 2015

[16] Notoadmodjo, S. 2007. Promosi Kesehatan dan Ilmu Perilaku. Jakarta: PT Rineka Cipta.

[17] Notoatmodjo, Soekidjo. 2010. Metodologi Penelitian Kesehatan. Edisi Revisi. Jakarta : Rineka Cipta

[18] Nugroho, W. 2005. Keperawatan Gerontik. Edisi 2. Jakarta: EGC

[19] Nugroho, W. 2008. Gerontik dan Geriatric. Jakarta: EGC

[20] Nursalam. 2007. Konsep dan penerapan metodelogi penelitian ilmu keperawatan: Pedoman skripsi, Tesis dan Instrumen penelitian keperawatan. Jakarta: Salemba Medika

[21] Nursalam. 2008. Konsep dan penerapan metodologi penelitian ilmu keperawatan. Jakarta: Salemba Medika.

[22] Nyman. 2007. Who do I need to improve my balance. Dari www. Balancetraining.org.uk.

[23] Perry \& Potter. 2005. Fundamental Keperawatan Konsep, Proses dan Praktik. Jakarta: EGC

[24] Perry \& Potter. 2008. Fundamental of Nursing: concepts, process and practice. Mosby-year book inc.

[25] Pudjiastuti, SS. 2003. Fisioterapi pada lansia. Jakarta: EGC

[26] Riwidikdo, H. 2010. Statistik Kesehatan. Mitra Cendekia Press: Yogyakarta.

[27] Siburian, Prima. 2006. Bagaimana memberdayakan kemamapuan fisik lansia.

www.waspada.co.id/cetak/index.php ?article id $=74423$

[28] Sugiyono. (2010) Statistika Untuk Penelitian. Bandung: Alfabeta Bandung.

[29] Taylor, Paul M. 2004. Mencegah dan Mengatasi Cedera Olahraga. Jakarta: PT Raja Grafindo Persada
[30] World Health Organization. (2003). Definition and Diagnosis of Diabetes Mellitus and Intermediate Hyperglycemia. Geneva: WHO Press 